\title{
Regulation of exercise-stimulated glucose uptake in skeletal muscle
}

Ho-Jin Koh, PhD

Applied Physiology Division, Department of Exercise Science, Arnold School of Public Health, University of South Carolina, Columbia, SC, USA

Received: 25 May, 2016

Accepted: 26 June, 2016

\section{Address for correspondence:}

Ho-Jin Koh, PhD

Applied Physiology Division, Department of Exercise Science, University of South Carolina, 921 Assembly St. Columbia, SC 29208, USA

Tel: $+1-803-777-1462$

Fax: +1-803-777-0558

E-mail:kohh@mailbox.sc.edu
AMP-activated protein kinase (AMPK) is a Ser/Thr kinase that has been thought to be an important mediator for exercise-stimulated glucose uptake in skeletal muscle. Liver kinase B1 (LKB1) is an upstream kinase for AMPK and AMPK-related protein kinases, of which the function in skeletal muscle has not been well documented. Our group and others have generated mice lacking AMPK activity in skeletal muscle, as well as muscle-specific LKB1 knockout mice. In this review, we discuss the potential role of AMPK and LKB1 in regulating exercise-stimulated glucose uptake in skeletal muscle. We also discuss our recent study, demonstrating the molecular mechanism of obesity-induced development of skeletal muscle insulin resistance.

Keywords: Skeletal muscle, Glucose uptake, Exercise, Obesity, Insulin

\section{Introduction}

The incidence of type 2 diabetes is increasing at epidemic rates worldwide and skeletal muscle is the tissue responsible for the majority of glucose disposal upon insulin stimulation and exercise, which have been known to increase glucose uptake into the tissue ${ }^{1)}$. Although the ability of insulin to promote glucose uptake into skeletal muscle is impaired, the exercisestimulated glucose uptake is nearly normal in the patients with type 2 diabetes ${ }^{2,3}$. Given the incidence of type 2 diabetes and the physiological importance of exercise in regulation of glucose uptake in skeletal muscle, it is important to understand the molecular mechanisms that mediate this phenomenon, which is still not fully understood.

\section{AMP-activated protein kinase and glucose uptake during exercise}

AMP-activated protein kinase (AMPK) is a Ser/Thr kinase that functions in the regulation of energy metabolism ${ }^{4)}$. Active AMPK consists of heterotrimeric complexes containing a catalytic $\alpha$ subunit and regulatory $\beta$ and $\gamma$ subunits. The phosphorylation of the $\mathrm{Thr}^{172}$ site on the a catalytic subunit by upstream kinase(s) is essential for AMPK activation ${ }^{5-7)}$. Liver kinase $\mathrm{B} 1(\mathrm{LKB} 1)^{5,8,9)}$ and $\mathrm{Ca}^{2+} / \mathrm{calmodulin}$ kinase kinase $(\mathrm{CaMKK})^{10-12)}$ have been shown to phosphorylate and activate AMPK. Recent studies have demonstrated that knockout of LKB1 in muscle results in a decreased AMPKa2 activity, suggesting that LKB1 appears to be a major AMPK kinase in skeletal muscle ${ }^{13,14)}$.

AMPK is activated upon increase in the AMP/ATP ratio, such as exercise ${ }^{15,16)}$ and hypoxia ${ }^{17)}$, and regulates multiple signaling pathways whose overall effects are to increase ATP production, including fatty acid oxidation and glucose uptake ${ }^{4,18}$. Consistently, incubation of isolated muscle with AICAR (5-aminoimidazole-4-carboxamide-1- $\beta$-D-ribofuranotide), an AMPK activator, stimulates glucose uptake in the absence of insulin, comparable to the effects of exercise and muscle contraction ${ }^{19-21)}$. Furthermore, lack of AMPK in skeletal muscle abolished the effect of AICAR to stimulate glucose uptake in skeletal muscle ${ }^{22,23}$. Collectively, these studies suggest that AMPK plays an important role in glucose uptake during exercise. 
Despite considerable effort has been made to understand the role of AMPK on exercise-stimulated glucose uptake using transgenic and knockout mouse models, the results are not consistent and are somewhat controversial. Transgenic mouse models depleting AMPK activity in a muscle-specific manner show different phenotypes; a partial impairment ${ }^{22,24,25}$ or no reduction ${ }^{23,26)}$ in exercise-stimulated glucose uptake. Furthermore, knockout of AMPKa1, AMPKa2, AMPK $\beta 2$, and $A M P K \gamma 3$ do not alter glucose uptake during in vitro contraction $^{27-29)}$. These data suggest that AICAR-stimulated increases in skeletal muscle glucose uptake are mediated by AMPKa2, but AMPK cannot be the sole mediator of contraction-stimulated glucose uptake. Although the role of AMPK in exercise-stimulated glucose uptake cannot be excluded, there may be multiple, potentially redundant, signaling mechanisms mediating contraction-mediated glucose uptake in skeletal muscle.

\section{Role of LKB1 and AMPK-related protein kinases in glucose uptake}

In order to determine the potential role of the AMPK upstream kinase, LKB1, our group has generated a musclespecific LKB1 knockout mouse (MLKB1KO) ${ }^{13)}$. Furthermore, Sakamoto et al. ${ }^{14)}$ have studied a hypomorphic LKB1 mouse where whole body LKB1 protein is decreased by $70 \%-80 \%$ and skeletal muscle LKB1 is ablated. Exercise-stimulated glucose uptake was significantly inhibited in these two LKB1 knockout mouse models ${ }^{13,14}$. The mechanism(s) by which LKB1 regulates exercise-stimulated glucose uptake in skeletal muscle has not been elucidated. We speculated that decreased glucose uptake cannot be explained by inactivation of AMPKa 2 alone and could be due to decreased activity of one or more other LKB1 substrates. In addition to AMPK, LKB1 has been known to phosphorylate at least 12 AMPK-related protein kinases that are similar in structure and/or function to AMPK ${ }^{30,31}$. The role of AMPK-related protein kinases in regulating skeletal muscle glucose uptake has not yet been understood but one report suggests that only some of the AMPK-related kinases (QSK, QIK, MARK2/3, and MARK4) are expressed in rat skeletal muscle, and that none of these proteins are activated by in situ muscle contraction ${ }^{32}$. Another study demonstrated that phosphorylation of the AMPK-related protein kinase 5 (ARK5) is increased by both muscle contraction and AICAR in rat skeletal muscle. However, the increased ARK5 phosphorylation was not associated with elevated enzyme activity in this study ${ }^{33)}$. Taken together, it is likely that exercise-stimulated glucose uptake is regulated by one or more alternative downstream substrates of LKB1.

\section{Role of SNARK in exercise-stimulated glucose uptake}

Studies using transgenic and knockout mouse models lacking AMPK activity in skeletal muscle and muscle-specific LKB1 knockout mouse model raise the possibility that one or multiple AMPK-related kinases play an important role in exercise-stimulated glucose uptake in skeletal muscle. The role of the proteins in this process has not been well understood and therefore remains to be elucidated. However, our group has recently reported that Sucrose Nonfermenting AMPKrelated Kinase (SNARK) plays an important role in exercisestimulated glucose uptake in skeletal muscle ${ }^{34)}$. The enzyme activity is activated by muscle contraction and exercise in mice and humans. Overexpression of dominant mutant SNARK by a direct DNA injection and heterozygotic SNARK knockout mice decrease SNARK activity in skeletal muscle, which is associated with impaired exercise-stimulated glucose uptake. More recently, SNARK has also been reported to regulate muscle mass ${ }^{35}$. The expression of SNARK in skeletal muscle is increased by high fat diet and aging. Transgenic mice overexpressing a dominant negative form of SNARK in skeletal muscle display a loss of muscle mass and an increased adiposity, showing a sarcopenic obesity (aging-related muscle mass loss and obesity). These findings indicate that SNARK plays important roles in muscle metabolism as well as muscle mass maintenance. Further studies are needed to determine the role of other AMPK-related protein kinases in skeletal muscle metabolism. Thus, LKB1 and its downstream pathway, including AMPK and SNARK, play an important role in exercise-stimulated glucose uptake and muscle metabolism.

\section{Skeletal muscle and insulin resistance}

The importance of skeletal muscle in the regulation of whole body glucose metabolism has been clearly established. In addition to exercise, insulin is a major mediator for glucose uptake in skeletal muscle. Most patients with type 2 diabetes display insulin resistance in skeletal muscle. Although the insulin signaling molecules have been well understood, the development of insulin resistance remains unclear. Our group recently studied the role of Tribbles 3 (TRB3) in skeletal muscle. TRB3 is a pseudokinase ${ }^{36)}$ that is expressed in various tissues, including liver, adipose tissue, heart and skeletal muscle ${ }^{13,37-39)}$, and its expression is regulated through multiple mechanisms. In liver and adipose tissue, TRB3 expression is induced by fasting via activation of PGC- $1 \alpha$ and PPAR- $\alpha^{37,38,40)}$. In 3T3-L1 adipocytes and L6 myotubes, glucose deprivation, dexamethasone, and the unfolded protein response regulate TRB3 expression $^{41}$. Endoplasmic reticulum (ER) stress is known to increase TRB3 expression in various cell lines ${ }^{42-44}$. TRB3 is induced by various forms of ER stress via enhanced promoter activity $^{44}$. These indicate that TRB3 is regulated by metabolic stress in multiple tissues. Recent studies demonstrate that TRB3 binds and inhibits Akt activity, leading to impaired insulin signaling in liver ${ }^{37,40}$. Our study found ${ }^{45)}$ that high-fat feeding in mice, and obesity and type 2 diabetes in humans increase TRB3 in skeletal muscle. Overexpression of TRB3 impairs insulin signaling and insulin-stimulated glucose uptake in skeletal 
muscle. Consistently, TRB3 knockout mice are protected from high-fat diet-induced insulin resistance in skeletal muscle. Taken together, these data strongly suggest that TRB3 mediates development of insulin resistance in skeletal muscle. Furthermore, the results demonstrate that TRB3 may be a new therapeutic target for effectively managing insulin resistance.

\section{Conclusions}

It has been clearly shown that AMPK activates glucose uptake in skeletal muscle, which is comparable to insulin. Skeletal muscle LKB1, an upstream kinase of AMPK and AMPKrelated protein kinases, has been shown to regulate exercisestimulated glucose uptake. The underlying mechanisms appear to be AMPK-independent and still need to be elucidated. SNARK, an AMPK-related protein kinase, plays an important role in exercise-stimulated glucose uptake in skeletal muscle. Further investigations need to be done to determine if the LKB1/SNARK pathway is a useful therapeutical target for the treatment of type 2 diabetes, as the role of the pathway in other tissues has not been studied. Our recent study also identified a novel protein, TRB3, as an important signaling molecule in developing insulin resistance in skeletal muscle. Inhibition of TRB3 function may assist in preventing obesity and type 2 diabetes.

\section{Conflict of interest}

No potential conflict of interest relevant to this article was reported.

\section{Acknowledgments}

The authors would like to acknowledge Ran Hee Choi and Abigail McConahay for their editorial contributions. This work was supported by NIH grants to H.J. Koh (AR066825-01A1) and departmental start-up grant to H.J. Koh.

\section{References}

1. DeFronzo RA, Ferrannini E, Sato Y, Felig P, Wahren J. Synergistic interaction between exercise and insulin on peripheral glucose uptake. J Clin Invest 1981;68:1468-74.

2. Kennedy JW, Hirshman MF, Gervino EV, Ocel JV, Forse RA, Hoenig SJ, et al. Acute exercise induces GLUT4 translocation in skeletal muscle of normal human subjects and subjects with type 2 diabetes. Diabetes 1999;48:1192-7.

3. Zierath JR, Krook A, Wallberg-Henriksson H. Insulin action in skeletal muscle from patients with NIDDM. Mol Cell Biochem 1998;182:153-60.

4. Hardie DG, Carling D, Carlson M. The AMP-activated/ SNF1 protein kinase subfamily: metabolic sensors of the eukaryotic cell? Annu Rev Biochem 1998;67:821-55.
5. Hawley SA, Boudeau J, Reid JL, Mustard KJ, Udd L, Makela TP, et al. Complexes between the LKB1 tumor suppressor, STRAD alpha/beta and MO25 alpha/beta are upstream kinases in the AMP-activated protein kinase cascade. J Biol 2003;2:28.

6. Crute BE, Seefeld K, Gamble J, Kemp BE, Witters LA. Functional domains of the alphal catalytic subunit of the AMP-activated protein kinase. J Biol Chem 1998;273:35347-54.

7. Stein SC, Woods A, Jones NA, Davison MD, Carling D. The regulation of AMP-activated protein kinase by phosphorylation. Biochem J 2000;345 Pt 3:437-43.

8. Abu-Elheiga L, Brinkley WR, Zhong L, Chirala SS, Woldegiorgis G, Wakil SJ. The subcellular localization of acetyl-CoA carboxylase 2. Proc Natl Acad Sci U S A 2000; 97:1444-9.

9. Shaw RJ, Kosmatka M, Bardeesy N, Hurley RL, Witters LA, DePinho RA, et al. The tumor suppressor LKB1 kinase directly activates AMP-activated kinase and regulates apoptosis in response to energy stress. Proc Natl Acad Sci U S A 2004;101:3329-35.

10. Hawley SA, Pan DA, Mustard KJ, Ross L, Bain J, Edelman $\mathrm{AM}$, et al. Calmodulin-dependent protein kinase kinasebeta is an alternative upstream kinase for AMP-activated protein kinase. Cell Metab 2005;2:9-19.

11. Woods A, Dickerson K, Heath R, Hong SP, Momcilovic M, Johnstone SR, et al. Ca2+/calmodulin-dependent protein kinase kinase-beta acts upstream of AMP-activated protein kinase in mammalian cells. Cell Metab 2005;2:21-33.

12. Hurley RL, Anderson KA, Franzone JM, Kemp BE, Means AR, Witters LA. The Ca2+/calmodulin-dependent protein kinase kinases are AMP-activated protein kinase kinases. J Biol Chem 2005;280:29060-6.

13. Koh HJ, Arnolds DE, Fujii N, Tran TT, Rogers MJ, Jessen N, et al. Skeletal muscle-selective knockout of LKB1 increases insulin sensitivity, improves glucose homeostasis, and decreases TRB3. Mol Cell Biol 2006;26:8217-27.

14. Sakamoto K, McCarthy A, Smith D, Green KA, Grahame Hardie D, Ashworth A, et al. Deficiency of LKB1 in skeletal muscle prevents AMPK activation and glucose uptake during contraction. EMBO J 2005;24:1810-20.

15. DeFronzo RA, Jacot E, Jequier E, Maeder E, Wahren J, Felber JP. The effect of insulin on the disposal of intravenous glucose. Results from indirect calorimetry and hepatic and femoral venous catheterization. Diabetes 1981;30:1000-7.

16. Dietze G, Wicklmayr M. Evidence for a participation of the kallikrein-kinin system in the regulation of muscle metabolism during muscular work. FEBS Lett 1977;74:2058.

17. Douen AG, Ramlal T, Rastogi S, Bilan PJ, Cartee GD, Vranic $\mathrm{M}$, et al. Exercise induces recruitment of the "insulinresponsive glucose transporter". Evidence for distinct intracellular insulin- and exercise-recruitable transporter pools in skeletal muscle. J Biol Chem 1990;265:13427-30.

18. Kemp BE, Mitchelhill KI, Stapleton D, Michell BJ, Chen 
ZP, Witters LA. Dealing with energy demand: the AMPactivated protein kinase. Trends Biochem Sci 1999;24:22-5.

19. Bergeron R, Russell RR 3rd, Young LH, Ren JM, Marcucci M, Lee A, et al. Effect of AMPK activation on muscle glucose metabolism in conscious rats. Am J Physiol 1999;276(5 Pt 1):E938-44.

20. Hayashi T, Hirshman MF, Kurth EJ, Winder WW, Goodyear LJ. Evidence for 5 ' AMP-activated protein kinase mediation of the effect of muscle contraction on glucose transport. Diabetes 1998;47:1369-73.

21. Merrill GF, Kurth EJ, Hardie DG, Winder WW. AICA riboside increases AMP-activated protein kinase, fatty acid oxidation, and glucose uptake in rat muscle. Am J Physiol 1997;273(6 Pt 1):E1107-12.

22. Mu J, Brozinick JT Jr, Valladares O, Bucan M, Birnbaum MJ. A role for AMP-activated protein kinase in contractionand hypoxia-regulated glucose transport in skeletal muscle. Mol Cell 2001;7:1085-94.

23. Fujii N, Hirshman MF, Kane EM, Ho RC, Peter LE, Seifert $\mathrm{MM}$, et al. AMP-activated protein kinase alpha2 activity is not essential for contraction- and hyperosmolarityinduced glucose transport in skeletal muscle. J Biol Chem 2005;280:39033-41.

24. Lefort N, St-Amand E, Morasse S, Cote CH, Marette A. The alpha-subunit of AMPK is essential for submaximal contraction-mediated glucose transport in skeletal muscle in vitro. Am J Physiol Endocrinol Metab 2008;295:E144754.

25. Lee-Young RS, Griffee SR, Lynes SE, Bracy DP, Ayala JE, McGuinness OP, et al. Skeletal muscle AMP-activated protein kinase is essential for the metabolic response to exercise in vivo. J Biol Chem 2009;284:23925-34.

26. Maarbjerg SJ, Jorgensen SB, Rose AJ, Jeppesen J, Jensen TE, Treebak JT, et al. Genetic impairment of AMPKalpha2 signaling does not reduce muscle glucose uptake during treadmill exercise in mice. Am J Physiol Endocrinol Metab 2009;297:E924-34.

27. Jorgensen SB, Viollet B, Andreelli F, Frosig C, Birk JB, Schjerling P, et al. Knockout of the alpha2 but not alpha $15^{\prime}$-AMP-activated protein kinase isoform abolishes 5-aminoimidazole-4-carboxamide-1-beta-4ribofuranosidebut not contraction-induced glucose uptake in skeletal muscle. J Biol Chem 2004;279:1070-9.

28. Steinberg GR, O'Neill HM, Dzamko NL, Galic S, Naim T, Koopman R, et al. Whole body deletion of AMP-activated protein kinase beta\}2 reduces muscle AMPK activity and exercise capacity. J Biol Chem 2010;285:37198-209.

29. Barnes BR, Marklund S, Steiler TL, Walter M, Hjalm G, Amarger $\mathrm{V}$, et al. The 5'-AMP-activated protein kinase gamma3 isoform has a key role in carbohydrate and lipid metabolism in glycolytic skeletal muscle. J Biol Chem 2004;279:38441-7.

30. Lizcano JM, Goransson O, Toth R, Deak M, Morrice NA, Boudeau J, et al. LKB1 is a master kinase that activates 13 kinases of the AMPK subfamily, including MARK/PAR-1.
EMBO J 2004;23:833-43.

31. Jaleel M, McBride A, Lizcano JM, Deak M, Toth R, Morrice NA, et al. Identification of the sucrose non-fermenting related kinase SNRK, as a novel LKB1 substrate. FEBS Lett 2005;579:1417-23.

32. Sakamoto K, Gooransson O, Hardie DG, Alessi DR. Activity of LKB1 and AMPK-related kinases in skeletal muscle: effects of contraction, phenformin, and AICAR. Am J Physiol Endocrinol Metab 2004;287:E310-7.

33. Fisher JS, Ju JS, Oppelt PJ, Smith JL, Suzuki A, Esumi H. Muscle contractions, AICAR, and insulin cause phosphorylation of an AMPK-related kinase. Am J Physiol Endocrinol Metab 2005;289:E986-92.

34. Koh HJ, Toyoda T, Fujii N, Jung MM, Rathod A, Middelbeek RJ, et al. Sucrose nonfermenting AMPK-related kinase (SNARK) mediates contraction-stimulated glucose transport in mouse skeletal muscle. Proc Natl Acad Sci U S A 2010;107:15541-6.

35. Lessard SJ, Rivas DA, So K, Koh HJ, Queiroz AL, Hirshman MF, et al. The AMPK-related kinase SNARK regulates muscle mass and myocyte survival. J Clin Invest 2016;126:560-70.

36. Wu M, Xu LG, Zhai Z, Shu HB. SINK is a p65-interacting negative regulator of NF-kappaB-dependent transcription. J Biol Chem 2003;278:27072-9.

37. Du K, Herzig S, Kulkarni RN, Montminy M. TRB3: a tribbles homolog that inhibits Akt/PKB activation by insulin in liver. Science 2003;300:1574-7.

38. Qi L, Heredia JE, Altarejos JY, Screaton R, Goebel N, Niessen S, et al. TRB3 links the E3 ubiquitin ligase COP1 to lipid metabolism. Science 2006;312:1763-6.

39. Avery J, Etzion S, DeBosch BJ, Jin X, Lupu TS, Beitinjaneh $\mathrm{B}$, et al. TRB3 function in cardiac endoplasmic reticulum stress. Circ Res 2010;106:1516-23.

40. Koo SH, Satoh H, Herzig S, Lee CH, Hedrick S, Kulkarni R, et al. PGC-1 promotes insulin resistance in liver through PPAR-alpha-dependent induction of TRB-3. Nat Med 2004;10:530-4.

41. Yacoub Wasef SZ, Robinson KA, Berkaw MN, Buse MG. Glucose, dexamethasone, and the unfolded protein response regulate TRB3 mRNA expression in 3T3-L1 adipocytes and L6 myotubes. Am J Physiol Endocrinol Metab 2006;291:E1274-80.

42. Carracedo A, Gironella M, Lorente M, Garcia S, Guzman M, Velasco G, et al. Cannabinoids induce apoptosis of pancreatic tumor cells via endoplasmic reticulum stressrelated genes. Cancer Res 2006;66:6748-55.

43. Corcoran CA, Luo X, He Q, Jiang C, Huang Y, Sheikh MS. Genotoxic and endoplasmic reticulum stresses differentially regulate TRB3 expression. Cancer Biol Ther 2005;4:1063-7.

44. Ohoka N, Yoshii S, Hattori T, Onozaki K, Hayashi H. TRB3, a novel ER stress-inducible gene, is induced via ATF4CHOP pathway and is involved in cell death. EMBO J 2005;24:1243-55. 
45. Koh HJ, Toyoda T, Didesch MM, Lee MY, Sleeman MW, Kulkarni RN, et al. Tribbles 3 mediates endoplasmic reticulum stress-induced insulin resistance in skeletal muscle. Nat Commun. 2013;4:1871. 